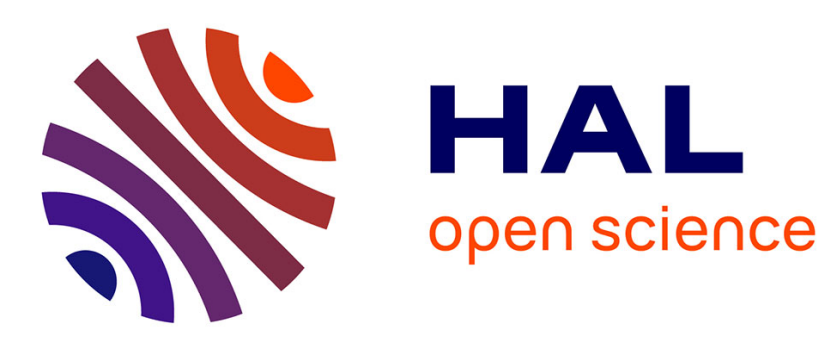

\title{
Influence of site and stand factors on Hymenoscyphus fraxineus-induced basal lesions
}

\author{
Benoit Marçais, Claude Husson, L. Godart, Olivier Cael
}

\section{To cite this version:}

Benoit Marçais, Claude Husson, L. Godart, Olivier Cael. Influence of site and stand factors on Hymenoscyphus fraxineus-induced basal lesions. Plant Pathology, 2016, 65 (9), pp.1452-1461. 10.1111/ppa.12542 . hal-01494738

\section{HAL Id: hal-01494738 \\ https://hal.science/hal-01494738}

Submitted on 10 Jan 2020

HAL is a multi-disciplinary open access archive for the deposit and dissemination of scientific research documents, whether they are published or not. The documents may come from teaching and research institutions in France or abroad, or from public or private research centers.
L'archive ouverte pluridisciplinaire HAL, est destinée au dépôt et à la diffusion de documents scientifiques de niveau recherche, publiés ou non, émanant des établissements d'enseignement et de recherche français ou étrangers, des laboratoires publics ou privés.

\section{다(1)(2)}

Distributed under a Creative Commons Attribution - ShareAlikel 4.0 International 


\title{
Influence of site and stand factors on Hymenoscyphus fraxineus induced basal lesions
}

\author{
B. Marçais, C. Husson, L. Godart, O. Caël \\ UMR IAM, INRA, Université de Lorraine, Nancy, F-54280 Champenoux, France
}

Key words Chalara ash dieback; canker, Armillaria; apothecia; spatial epidemiology

\section{Summary}

Hymenoscyphus fraxineusis an invasive fungus in Europe and causes a severe decline affecting ashes since the late nineties. One of the symptoms associated with the disease is lesions in the outer bark of the collar area. However, the etiology of these basal lesions and in particular the relative role of $\mathrm{H}$. fraxineus and Armillaria species is still controversial; moreover, little is known on the influence of environmental factor on the disease epidemiology. We therefore surveyed 42 plots located in Northeastern France, in an area affected by ash decline since 2008 in order to determine which environmental factors condition the severity of lesions associated with $H$. fraxineus on ash collar. The spatial pattern that is the consequence of the invasive spread of the disease was taken into account in the analysis using a spatial hierarchical Bayesian model fitted by Integrated Nested Laplace Approximation (INLA). Results show that while basal lesions are tightly associated with $\mathrm{H}$. fraxineus, their severity is not linked to the Armillariaspecies present in the plot. Sites with vegetation indicating moist condition or more humid topographical position were associated with more developed basal lesion.

\section{Introduction}

Since the 1990s, a new fungal disease causes severe damages in ash populations in Europe, mainly on Fraxineus excelsior. Firstly reported in Poland (Kowalski, 2006), ash dieback is now present in most of Europe, widespread between 45th and 60th parallel north (McKinney et al., 2014). The causal agent, Hymenoscyphus fraxineus (anamorph Chalara fraxinea) is an introduced and invasive ascomycete most likely originated from Eastern Asia where it infects indigenous ashes such as F. mandshurica with limited damages (Gross and Holdenrieder, 2015). In summer, fruit body formation occurs in the litter on the leaf rachis of the previous year, releasing infectious ascospores which cause leaf and shoot lesions and xylem necrosis. Multiplication of infection in the crown results in widespread branch mortality and severe crown dieback with development of epicormic shoots. The disease may lead to tree death in particular in F. excelsior seedlings (Gross et al., 2014).

In very infected areas, another important symptom of ash dieback is lesions at the stem base, which progress towards xylem and heartwood and cause collar rot and canker on mature trees (Husson et al., 2012). A few studies were carried out in very infected countries to understand etiology of such symptoms. In Denmark and Lithuania, Armillaria species, particularly A. gallica and A. cepistipes, were identified as the main cause of lesions at stem base and root rot. These pathogens were often associated with declining trees, acting as secondary pathogens on weakened individuals (Skovsgaard et al., 2010; Bakys et al., 2011). In addition, in Germany, Enderle et al. (2013) showed that the occurrence of collar rots is highly spatially correlated at plot scale, supporting that Armillaria sp. is probably the causal agent of collar lesion. Moreover, the soil-borne pathogens Phytophthora spp. were suggested to be involved in ash decline as well, based on isolation from root and collar rot and on pathogenicity tests (Orlikowski et al., 2011). However, this hypothesis was not confirmed by additional studies which showed the absence of Phytophthora spp. from investigated samples (Bakys et al., 2009; Husson et al., 2012; Schumacher, 2011). Finally, Husson et al. (2012) showed that $H$. fraxineus (formerly H. pseudoalbidus) was involved in the lesion induction in Northeastern France, rather than Amillaria sp., arguing that the pathogen was frequently detected from collar necrosis using molecular tools and can cause collar canker in a Armillaria-free forest stand. Consequently, the identity of pathogen species causing the collar lesions on mature trees base remains controversial, and in particular the exact role played by each of the three main pathogens cited above in the infection process at the collar level. Moreover, it might be possible that several pathogens interact on the ash collar to produce the damage as was evidenced by Marçais et al. (2011) for oak 
root rot. Indeed the authors showed that the joined infection of oak seedlings by several root rot / Phytophthora species produced damages that were larger than the addition of each pathogen induced damages.

To date, the role of environmental factors on disease intensity is poorly studied. The fact that ash dieback pathogen is an introduced pest with a still ongoing spread and the strong dependence of damage on time since disease arrival makes it difficult to assess the importance of environmental parameters on disease development (Husson et al., 2012). However, the large-scale occurrence of $H$. fraxineus in Europe suggests that the pathogen tolerates a wide range of environmental conditions (Gross et al., 2014). At stand level, among parameters associated with the disease, moist soil conditions proved to be conducive to the development of collar lesions, probably because suitable either for apothecia production or for Armillaria sp. infection (Enderle et al., 2013; Husson et al., 2012). However, investigation on the relationship between inoculum density of both pathogens and severity of either crown decline or collar lesion is missing for a better understanding of this phenomenon. By contrast, stand density and origin (planting versus regeneration from seedling) were found to be not correlated to disease severity (Bakys et al., 2013; Husson et al., 2012). Accordingly, lack of knowledges concerning involvement of environmental conditions in ash dieback and collar canker hampers the development of disease management strategies, suggesting the necessity of additional ecological studies.

In this work, we therefore aimed at testing several hypotheses, i.e. that (i) collar girdling by basal lesion depends both on site factors and presence of Armillaria species, (ii) amount of inoculum produced in the litter is influenced by site conditions and could decrease as crown decline increases because less foliage is present and that (iii) the girdling of collar by basal lesions depends on the amount of inoculum produced because it results from the accumulation of new infections of the collar and not so much on the enlargement of existing lesion over the years..

\section{Material and Methods}

\section{Plot selection}

Altogether, 42 plots were studied. The plots were selected in the department of Haute-Saône and Vosges which represent the first area where $H$. fraxineus was reported in France in 2008 and where the disease thus had had several years to increase in severity (Fig. 1). Only stands where $H$. fraxineus was known to be present were selected without consideration for disease severity (data from Département de la Santé des Forêts, the forest health survey system). The next criterion used was the presence of at least 25 ashes at the pole stage. We then chose the plots in order to encompass the diversity of sites with ash presence within the area. In particular, to determine what role Armillaria sp. may play in the disease evolution, we selected either plots within plantations in former agricultural settings where Armillaria sp. tend to be in low frequency (8 plots) or plots within former forests settings where Armillaria sp. are usually abundant (19 plantations and 15 stands originating from natural seeding). The plot coordinates were determined with a GPS.

\section{Tree health survey}

Twenty five ash trees in each plot were selected on a transect which length depended on the ash density and they were mapped and marked for health monitoring. Two different damages induced by $H$. fraxineus, crown decline and collar canker, were rated. The collar of the selected trees was examined for presence of canker at 2 periods, in May 2011 and in March 2012. The collar area was lightly scratch with a knife and the number of distinct basal lesions was determined as well as the width and height above soil level of each of those lesions. The total collar circumference was then measured. The crown status of the selected trees was rated in May 2011 on a 0 to 4 scale: 0 , no decline signs; 1 , decline affecting less than $10 \%$ of the crown ; 2 , decline affecting $10-50 \%$ of the crown ; 3 , decline affecting more than $50 \%$ of the crown and 4 , tree dead. At the plot establishment in spring 2011 , only living trees were selected. The crown rating was done end of May, after budburst but before a possible refoliation that might have masked some crown decline symptoms.

On each plot with collar cankers, sampling was done on 3 different trees scattered within the plot to assess the presence of pathogens in the collar lesions. On each tree, bark tissue was sampled at the margin of the collar lesions to detect $H$. fraxineus / Phytophthora sp. or for Armillaria sp., by seeking mycelial fans in the older part of the lesion. Whenever no collar canker was observed on the plot, shoots with putative $H$. fraxineus symptoms were sampled. The samples were brought back to the laboratory and kept at $5^{\circ} \mathrm{C}$ until analysis.

Presence of $H$. fraxineus was assessed by molecular method. Pieces of bark at the margin of discoloured area were cut using a scalpel. To avoid contamination, latex gloves were used during the handling and the scalpel blade was changed between each tree. Approximately $100 \mathrm{mg}$ of chipped phloem was placed in a $2-\mathrm{ml}$ Eppendorf tube. Healthy bark pieces sampled in area without discoloration were also collected as negative control. DNA extractions were performed as described in Husson et al. (2012). Amplifications with the speciesspecific primer pairs and probe Cfrax-F/-R-/-P for $H$. fraxineus (loos et al., 2009) were performed in a $15 \mu \mathrm{L}$ 
reaction volume consisting of ultra-pure water, $7.5 \mu \mathrm{L}$ of Brilliant III Ultra-Fast QPCR Master Mix (Agilent, Les Ulis, France), $0.3 \mu \mathrm{M}$ of each primer, $0.1 \mu \mathrm{M}$ of dual-labelled probe, $0.15 \mathrm{U}$ of Uracil-N-Glycosylase (UNG), 30 $\mathrm{nM}$ of ROX reference dye and $2 \mu \mathrm{L}$ of template DNA. Real-time PCR was carried out in a Stratagene Mx3005P. The PCR cycling conditions included an initial step for UNG activation for 2 min at $50^{\circ} \mathrm{C}$, a Taq polymerase activation step for $10 \mathrm{~min}$ at $95^{\circ} \mathrm{C}$ followed by 40 cycles of denaturation at $95^{\circ} \mathrm{C}$ for $15 \mathrm{~s}$, and annealing and elongation at $65^{\circ} \mathrm{C}$ for $55 \mathrm{~s}$. The Ct value for each reaction was automatically determined using the Mx-Pro software version 4.1 (Agilent, Les Ulis, France).

Isolation was attempted from the samples taken to detect Armillaria and Phytophthora species. For Phytophthora sp. detection, samples were incubated in distilled water during 3 hours. For Armillaria sp. detection, samples were washed under tap water, surface sterilized (1 min in sodium hypochlorite at 3.75\% active chlorine) and rinsed 2 times in sterile water. Chips of bark with the margin between healthy or necrotic tissue for Phytophthora or with mycelial fans for Armillaria were then plated on selective media (V8A for

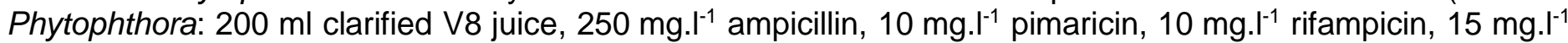
benomyl, 50 mg. $\mathrm{I}^{-1}$ hymexazol and $15 \mathrm{g.} \mathrm{I}^{-1}$ agar or MAT for Armillaria: $10 \mathrm{g.} \mathrm{I}^{-1}$ of malt Difco, $100 \mathrm{mg}^{-1}$ penicillin, $100 \mathrm{mg} . \mathrm{I}^{-1}$ streptomycin, $250 \mathrm{mg.I^{-1 }}$ thiabendazole and $15 \mathrm{g.l}^{-1}$ agar) and incubated in the dark. Mycelium outgrowing from the bark tissues after 1-2 weeks were sampled and placed on malt extract medium before further characterisation. Armillaria isolates were determined to the species by haploid / diploid pairing using the method described in Guillaumin and Berthelay (1981). Each isolate was paired with 3 haploid tester strains for each of the 3 species $A$. cepistipes, $A$. gallica and $A$. mellea.

\section{Pathogen inoculum abundance}

The inoculum level of both Armillaria and $H$. fraxineus was determined in the study.

Armillaria epiphytic rhizomorphs abundance on ash tree collars was determined as a measure of the pathogen inoculum potential using the method developed in Marçais and Caël (2006) in spring 2011. On each of the studied plots, 5 ash trees with no collar canker scattered within the 25 marked ashes were selected for this measurement. Briefly, soil at the collar of the studied trees was removed to expose the bark surface at 2 locations, on the part of the collar facing North and South, taking care not to disturb the rhizomorph network. The frequency of Armillaria rhizomorph was determined on a $5.5 \times 5.5 \mathrm{~cm}$ grid with 25 circular holes $6 \mathrm{~mm}$ in diameter. Only rhizomorphs firmly attached to the bark surface were taken into account. The density of epiphytic rhizomorphs on the collar can be estimated from this frequency according to the formula: $\log (\mathrm{RDW})=3.043 \times \mathrm{Pr}-0.514$, with $\mathrm{Pr}$, \% of the 25 plastic sheet holes with presence of epiphytic rhizomorphs and RDW the dry weight of rhizomorphs on the collar in mg.cm-2 (Marçais and Caël, 2006). The plot density of Armillaria epiphytic rhizomorph was then computed as the mean of the 10 measurements (2 per tree $\times 5$ ash trees).

A measure of $H$. fraxineus inoculum was also performed. For that, we determined the abundance of ash rachis in the soil litter as well as the number of the $H$. fraxineus-like apothecia that were growing on them in June 2011. This was done on $50 \times 50 \mathrm{~cm}$ quadrats located at the base of 6 ash trees per plot; the trees were selected systematically every fourth marked ash tree, starting with the second to avoid over representing severely infected trees. The quadrats were located $1 \mathrm{~m}$ north to selected trees. All ash rachis located on the quadrats were sampled during the 2 last weeks of June 2011 and brought back to the laboratory. The total number of Hymenoscyphus sp. apothecia per sample was determined and 2 apothecia per quadrat were sampled for species identification by molecular method as previously described. The aim was to check whether $H$. fraxineus was indeed representing the majority of the apothecia; the sampling is too limited to derive any meaningful information on $\mathrm{H}$. albidus presence or absence. The rachis were then dried at $50^{\circ} \mathrm{C}$ and weighted. 

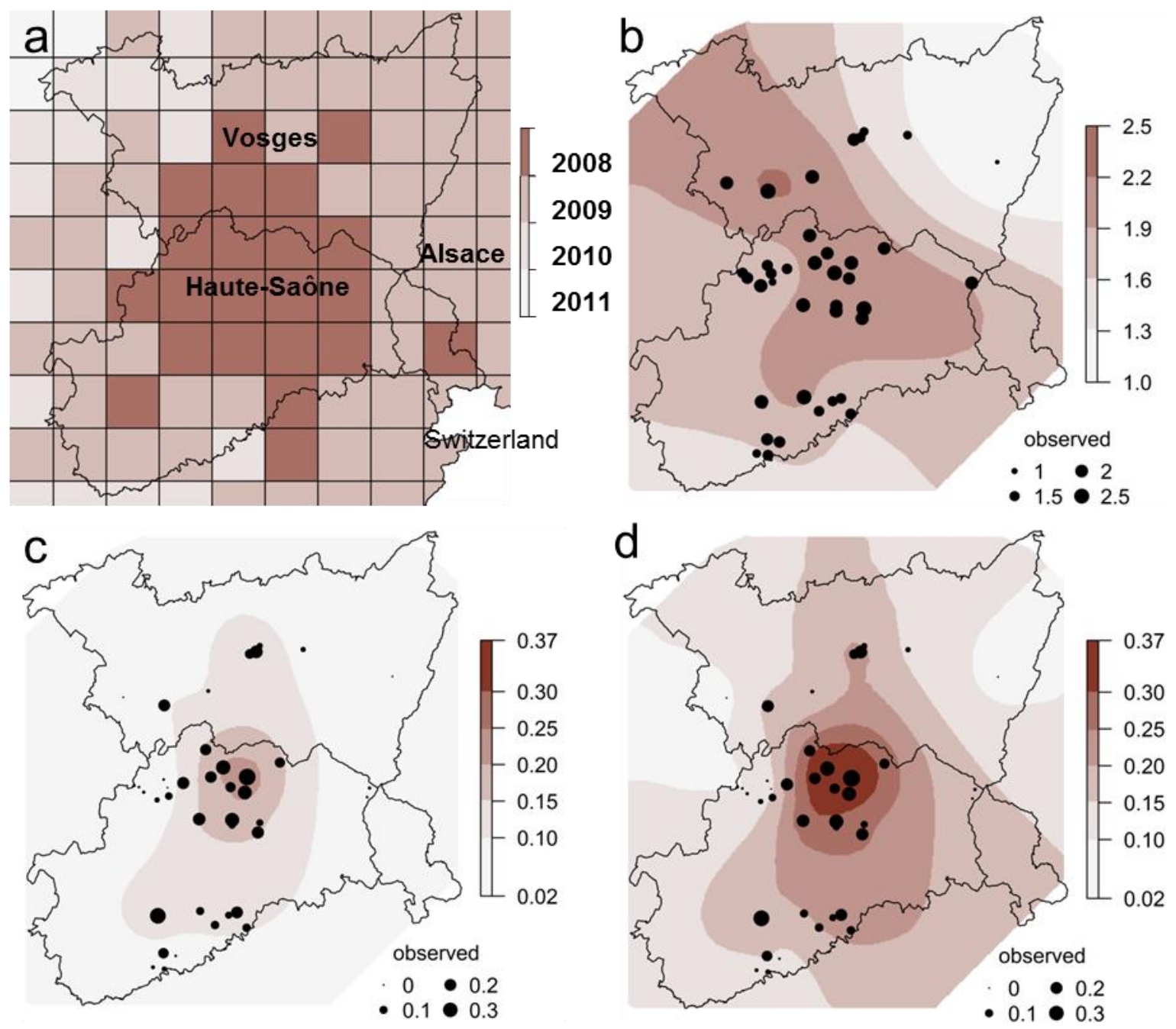

Figure 1. Spatial structure in disease severity; a; Year of first report of $H$. fraxineus by the health survey system (Département de la Santé des Forêts). b. Ash crown decline index in 2011. c, d. \% collar girdled by the basal canker in 2011 (c) and 2012 (d). Heat maps shown in b, c, d are results of the model including only the spatially structured random effect and the intercept for respectively crown decline in 2011, collar girdling in 2011 and collar girdling in 2012 while the black circles (observed) represent the measured values for these variables.

\section{Site characteristics}

The site was characterised for each of the studied plot during the spring 2011. Stand features rated were the ash tree diameter at breast height and the percent of ash within dominant / codominant trees of the site. Other site characteristics rated were presence of a stream/river in the vicinity, topography (plateau, mid or upper slope, lower slope or gully, alluvial flooded area, flat non alluvial area), plantation or stand originating from natural seedling and for plantations, nature of the previous land use, i.e. agriculture or former forest.

Soil characteristics were assessed by observation of a soil core extracted with an earth auger. Soils were described specifically for the degree of waterlogging, i.e. depth at which appear the first signs of anoxia (reddish traces of insoluble oxidized iron deposition and / or discoloration indicating iron depletion). The $\mathrm{pH}$ of the first 5 $\mathrm{cm}$ mineral soil was assessed at 3 locations per plot and the plot mean value was computed.

The plot vegetation was also characterised. A $25 \times 25 \mathrm{~m}$ plot was established and the \% cover of the herbaceous layer on this plot was determined to the nearest $10 \%$ in order to test whether the amount ground vegetation might influence the humidity experienced by the ash rachis and the pathogen fruiting. The plants species present on the plot (herbaceous, moss and shrubs) were determined to the species as they can provide good indicators of the site condition. In particular, to characterise the plot humidity from the vegetation, we used Landolt's indicator values (Landolt 1977) for soil moisture (F). Landolt's indicator values were used in preference of others because they were established in Switzerland, close to our study area. The plot moisture was determined as the average of the $\mathrm{F}$ value of all plants observed on the site. 
The collar girdling by basal lesions was computed as $\sum_{\mathrm{i}} \mathrm{LWi} / \mathrm{CC}$, with $\mathrm{LW}_{\mathrm{i}}$, the width of individual lesions $\mathrm{i}$ present on the tree collar and CC, the tree collar circumference. Then, the average plot level of crown decline and collar girdling (hereafter called canker severity) were computed and will be studied in the following analysis. A strong spatial pattern was present in the infection level of $H$. fraxineus, with much more severe disease observed in the north of Haute-Saône and south of Vosges compared to the rest of the studied area; these locations correspond to the place of the first report of Chalara ash dieback in France in 2008 (Fig. 1a) and could be the initiation point of the focus in the area. To properly assess the effect of environmental factor on the disease, this spatial effect had to be taken into account. To do that, we fitted spatially explicit Bayesian hierarchical models using R-INLA (www.r-inla.org, Rue et al., 2009). The fitted model was:

$f\left(\mu_{t}\right)=X_{t} \cdot \beta+A_{t} \cdot \omega_{i}$

where $\mu_{t}$ the mean of the analysed disease severity for the studied plots $t\left(t=1,2, \ldots n_{t}\right), X_{t}$ the design matrix containing the environmental covariates (including the intercept), $\beta$ the vector of parameters, $A_{t} . \omega_{i}$, a spatially structured random effect and $f$ the link function.

For the number of apothecia in the litter per ash rachis dry weight (ADW), a Gaussian distribution with identity link was used. The plot of residuals versus predicted and the normal Q-Q plot were examined to check the assumption of Gaussian distribution. For crown decline, the Gamma family distribution with a log link was used. Mean crown decline per site is a continuous variable that takes values between 0 and 4 . However, in practice the mean crown decline value remained lower than 2.6, far from the theoretical maximal value and the Gamma distribution that takes positive values was well suited. Finally, for collar canker severity which is a proportion of collar girdled, a Beta distribution with a logit link was assumed. We used the SPDE approach (Lindgren et al., 2011), estimating the underlying spatial Gaussian field $\omega$ at a set of $m$ regularly placed positions $w_{i}(i=1,2,3, \ldots m)$; the matrix $A_{t}$ of dimension $n_{t} \times m$ is thus used to interpolate the spatial Gaussian field $\omega_{i}$ to the studied locations $t=1,2, \ldots n_{t}$. The $m$ locations $w_{i}$ are related to each other through the Euclidian distances $d_{i j}=\left\|w_{i}-w_{j}\right\|$ so that the spatial pattern is isotropic and stationary. The term $\omega_{i}$ is Gaussian with a zero mean and a spatially structured covariance matrix $\sigma^{2} . I+\sigma_{i}^{2} \cdot C\left(d_{i j}, K, v\right)$, with $\sigma^{2}$, the nugget effect, I a diagonal identity matrix of dimension $\mathrm{m} \times \mathrm{m}, \sigma_{\mathrm{i}}^{2}$ the marginal variance of the process and $\mathrm{C}$ a function of the Matérn family with an unknown scale parameter $\mathrm{k}$ and a shape parameter $\mathrm{v}$ fixed at 1 . The 3 hyper parameters $\sigma^{2}, \sigma_{\mathrm{i}}^{2}$ and $\mathrm{k}$ were estimated during the fitting process according to default INLA procedures (Blangiardo et al, 2013).

A first model was fitted, including only the spatially structured random effect and the intercept. The mesh was built with maximal edges of 5 and $15 \mathrm{~km}$ for inner and outer mesh section, a cutoff of $3 \mathrm{~km}$, and an offset of 10 and $25 \mathrm{~km}$ for the inner and outer mesh section. We used default non informative priors for the model parameters $\beta$ and hyper parameters, $k, \sigma^{2}$ and $\sigma_{i}^{2}$. Then the relationship of each environmental variable was assessed by comparing the model with the environmental variable and the spatially structured random effect to the model with only the spatially structured random effect. The significance was assessed using the credibility interval $(\mathrm{Cl})$ for the parameter(s) i.e. $\mathrm{Cl}$ not including 0 . The environmental variables tested where log(distance to the river), origin (plantation or seeds from previous stand), previous land use (forest, agriculture), ash trees mean $\mathrm{dbh}$, percent of ash in the stand, topography (5 categories), soil $\mathrm{pH}$, soil texture (3 categories), soil water logging (depth of hydromophy signs appearance in the soil), \% cover of the herbaceous layer, mean Landolt indicator values for soil moisture (F), mean density of Armillaria epiphytic rhizomorph on Ash trees collar and Armillaria presence on the plot (in 2 categories, absent or present).

The relationship between mortality in 2012 and \% collar girdled by the basal canker in 2011 was studied by logistic regression, grouping trees per plots and per girdling categories of $0-50,50-75$ and more than $75 \%$. The model was fitted under a Bayesian frame using JAGS 4.2.0. Non-informative priors were assigned to the model parameters according to a normal distribution $\mathrm{N}(0,1 \mathrm{e}+06)$. The model was fitted with a burn-in of 50000 , for 60000 iterations with a thinning of 10 . Three parallels chains with overdispersed initial parameter values were run and convergence was checked by a Gelman-Rubin test ( $R_{\text {hat }}$ were close to 1$)$. 


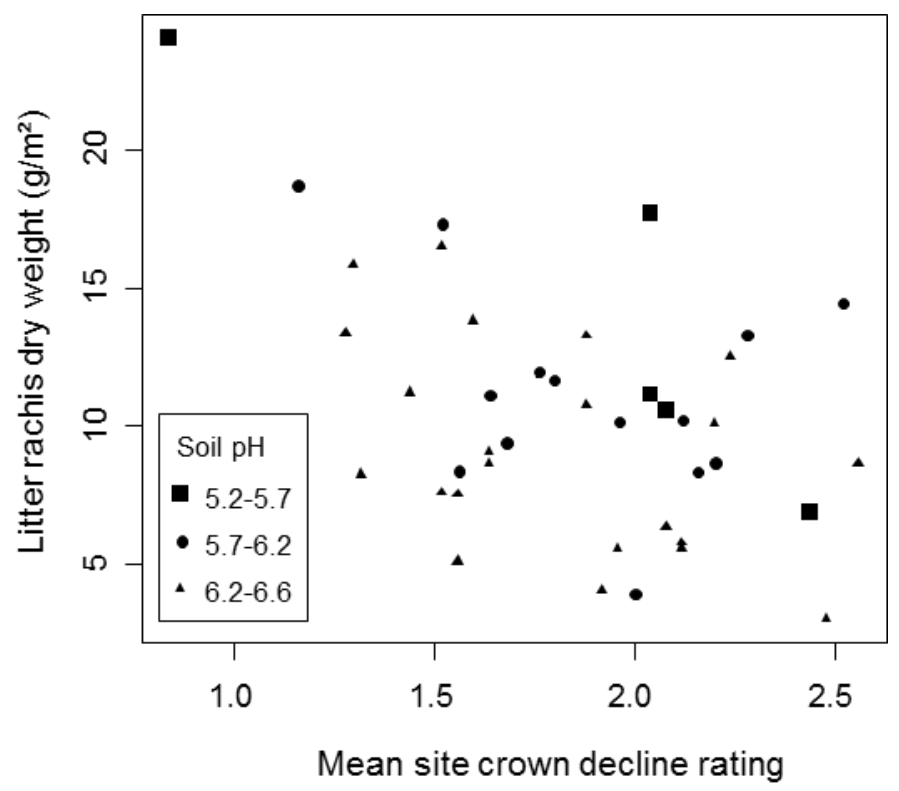

Figure 2. Ash rachis dry weight (ADW) in the soil litter.

\section{Results}

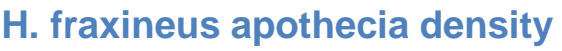

All apothecia analysed by PCR assay were $H$. fraxineus; $H$. albidus was not detected on the studied plots. The amount of apothecia in the forest litter showed a strong variability with a density that ranged from 30 to 2000 apothecia. $\mathrm{m}^{-2}$ (mean 710 apothecia.m $\mathrm{m}^{-2}$, interquartile interval of $\left.380-870\right)$. This density of apothecia was strongly linked to the ADW in the litter (Pearson $r=0.636, p<0.001$ ).

In a first step, we looked what might explain the amount of ash rachis in the soil litter, which ranged from 4 to 20 g.m $\mathrm{m}^{-2}$ of ADW. As it significantly decreased with ash trees crown status ( $\left.F=11.6, p=0.002\right)$, we tested other variables by adding them in a model already containing the tree decline status. ADW in the litter was significantly related to soil $\mathrm{pH}$ (Fig. $2, \mathrm{~F}=7.0, \mathrm{p}=0.012$ ), but not with any of the other tested site variables (results not shown).

The mean amount of apothecia was of $68.5 \mathrm{~g}^{-1}$ ADW (interquartile interval of 47.1-87.5). Some spatial structure was observed for the number of apothecia per ADW in the litter (Fig. 3). However, it could mainly be explained by spatial structure in the crown decline. Indeed, the DIC for the null model, the model with both crown decline in 2011 and the spatially structured random effect, with crown decline in 2011 only or with the spatially structured random effect only were respectively of $414.1,408.5,408.0$ and 410.5 . Thus, the model with only crown decline in 2011 had the lower DIC. The amount of apothecia in the litter per ADW increased with the amount of crown decline with a size effect of 27.7 (credibility interval of $11.7-47.7$ ). No clear pattern of higher apothecia number $\mathrm{g}^{-1}$ ADW in the north of Haute-Saône and south of Vosges could be observed and the pattern thus did not match the ones seen for decline and basal canker severity (Fig.1b-c-d, Fig. 3), indicating that, although the eastern plots might have fewer apothecia in the litter, the previous year foliar infection had been relatively uniform over the area. The amount of apothecia in the litter was otherwise significantly correlated to none of the site and stands factor studied (result not shown). Additionally, unlike the ADW in the litter, the number of apothecia per unit surface was significantly linked to neither ash trees crown status nor the soil pH (respective pvalue of 0.85 and 0.33 ). 


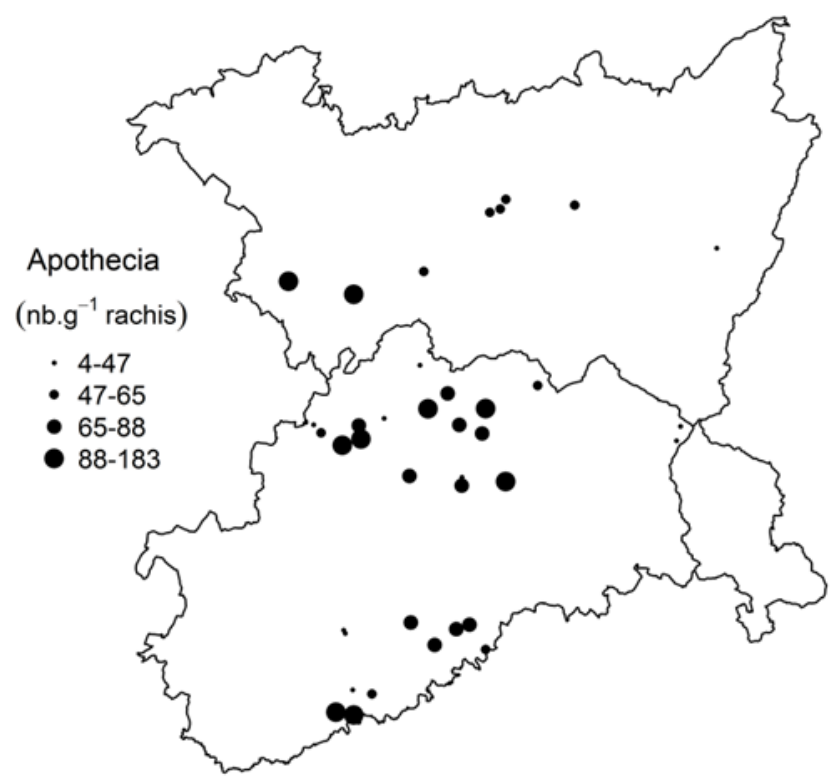

Figure 3. Density of $H$. fraxineus apothecia in the soil litter (number per $g$ of ash rachis dry weight, i.e. ADW).

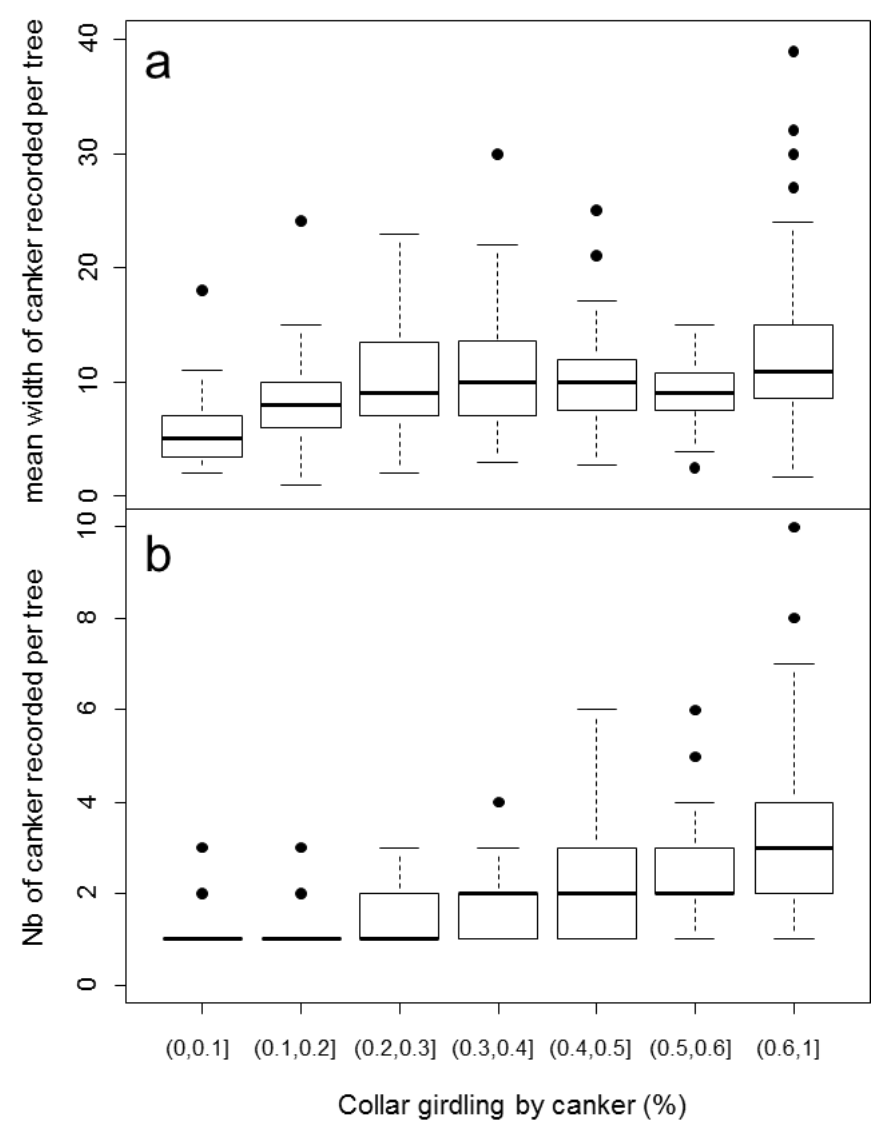

Figure 4. Number and width of lesions observed on the collar of individual ash trees.

\section{Disease severity}

The decline of ash tree was severe across the studied plots; altogether $63.1 \%$ of the trees were rated as declining with $39.8 \%$ rated as 2 (10-50\% of the crown declining) and $23.3 \%$ rated as 3 (more than $50 \%$ of the crown declining). A strong variability existed within the plot with a mean plot crown declining rating ranging from 0.8 to 2.6. The main reason explaining this variability was a clear spatial pattern in disease severity (Fig.1b). The model with a spatially structure random effect was selected as it DIC was of 24.9 compared to 44.9 for the 
null model, i.e. with only the intercept. The pattern of higher decline severity in the north of Haute-Saône and south of the Vosges correspond to the timing of first record of the disease presence in the area (Fig.1a).

A similar spatial pattern was found for the collar canker severity (Fig. 1c and d, DIC of the null model of 56.6 and 70.1 in 2011 and 2012 compared to a DIC of 43.3 and 57.4 in 2011 and 2012 for the model with the intercept and the spatially structure random effect.). A basal canker could be observed on $40.5 \%$ of the studied ash trees in 2011 and on $52.4 \%$ in 2012. Although the spatial pattern was similar, a clear increase in canker severity could be seen in 2012 compared to 2011. In the most severely affected area the average collar girdling by the basal lesion was of 20-25\% in 2011 and 30-37\% in 2012 (Fig. 1).

At the tree level, girdling of the collar by cankers was clearly associated with an increase in the number of lesion recorded per tree (Fig. 4). While trees with less than $20 \%$ of the collar girdled usually had just one canker, those with $40-60 \%$ of the collar girdled had a median number of 2 and those with over $60 \%$ of the collar girdled a median number of 3 . By contrast, above $10 \%$ girdling, the mean lesion width remained stable (Fig. 4a). Most of the cankers did not reach high levels above the soil line. Indeed, $67.5 \%$ of the cankers were less than $25 \mathrm{~cm}$ high while only $7.3 \%$ reached over $50 \mathrm{~cm}$ from soil level.

These basal cankers were strongly associated with $H$. fraxineus; the pathogen was detected by the molecular test in all of the studied plots, and from the basal canker of 79 out of the 89 tested ash trees (89\%). By contrast, Phytophthora sp. were isolated from none of the 79 tested collar canker and Armillaria sp. from the collar canker of 70 out of the 126 tested ash trees (55\%). Altogether, nothing (3\%), only either Armillaria sp. (8\%) or $\mathrm{H}$. fraxineus (42\%) or both Armillaria sp. and $\mathrm{H}$. fraxineus (47\%) were detected on the trees. At the plot level, Armillaria could not be observed from $33 \%$ of the stands, mostly plots with agricultural former land use. In those plots, the association between $\mathrm{H}$. fraxineus and the basal cankers was even tighter as the pathogen could be detected from $93 \%$ of the cankers (28/30). Several Armillaria species were identified from the isolates retrieved from the basal lesions. The most frequent was $A$. gallica that could be isolated on 57 trees (23 stands) while $A$. mellea could be isolated on seven trees (from six stands) and $A$. cepistipes on six trees (three stands). Presence of Armillaria on infected trees was usually associated with extensive rot of the collar of affected ashes.

Little ash mortality associated with $H$. fraxineus was observed during the investigation, i.e. 4 years after the first detection of the disease in the area. In 2012, only 926 ash trees could still be found back, mainly because 4 plots were clear-cut during the 2011-12 winter. Fourteen of these 926 ashes were dead (1.5\%). The mortality was significantly associated with the \% collar girdled by the canker in 2011 . Compared to trees with $0-50 \%$ of the collar girdled, the odd ratio for trees with $50-75 \%$ of the collar girdled was of $2.8(95 \%$ credibility interval, i.e. Cl: $0.1-11.9)$. This odd ratio was of $26.7(\mathrm{Cl} 5.3-77.8)$ for trees with over $75 \%$ of the collar girdled. The mortality was respectively of $1.1 \%(\mathrm{Cl} 0.5-1.8), 2.5 \%(\mathrm{Cl} 0.0-9.1)$ and $19.1 \%(\mathrm{Cl} 5.8-38.1)$ for ash trees with a girdling of the collar of $0-50 \%, 50-75 \%$ and over $75 \%$. 
Table 1. Results of the gamma regression for crown decline severity in 2011.

\begin{tabular}{|c|c|c|c|}
\hline \multirow{2}{*}{\multicolumn{2}{|c|}{$\begin{array}{l}\text { Model } \\
\text { SSRE }^{c}\end{array}$}} & Parameter $^{a}$ & $\overline{\mathrm{DIC}^{\mathrm{b}}}$ \\
\hline & & & 2 \\
\hline \multicolumn{2}{|l|}{ + origin } & $0.053[-0.075,0.185]$ & 25. \\
\hline \multicolumn{2}{|l|}{+ land use } & $-0.003[-0.182,0.176]$ & 26 \\
\hline \multicolumn{2}{|l|}{$+\log$ (dist. to river) } & $-0.057[-0.006,0.120]$ & 21 \\
\hline \multicolumn{2}{|l|}{$+\log ($ tree $\mathrm{dbh})$} & $-0.201[-0.370,-0.034]$ & 20. \\
\hline \multicolumn{2}{|l|}{$+\%$ ash in stand } & $0.000[-0.002,0.001]$ & $26 . \varepsilon$ \\
\hline \multirow[t]{5}{*}{+ topography $^{d}$} & LS & & 31. \\
\hline & MS & $0.046[-0.188,0.282]$ & \\
\hline & $\mathrm{PI}$ & $-0.014[-0.174,0.145]$ & \\
\hline & FLL & $-0.078[-0.268,0.115]$ & \\
\hline & AlF & $-0.047[-0.230,0.136]$ & \\
\hline \multicolumn{2}{|l|}{ + soil pH } & $-0.086[-0.266,0.093]$ & 25 \\
\hline \multicolumn{2}{|l|}{ + waterlogging } & $-0.001[-0.004,0.001]$ & 26 . \\
\hline \multicolumn{2}{|l|}{ + \%herbaceous cover } & $-0.001[-0.004,0.002]$ & 26. \\
\hline \multicolumn{2}{|l|}{ + Landolt F } & $-0.158[-0.394,0.075]$ & 27. \\
\hline \multicolumn{2}{|l|}{ + Armillaria presence } & $-0.010[-0.202,0.183]$ & 26. \\
\hline
\end{tabular}

a Mean $(95 \%$ credibility interval, $\mathrm{Cl})$ Significant results $(\mathrm{Cl}$ does not include 0$)$ are shown in bold font.

${ }^{b}$ Deviance Information Criteria

c SSRE: model with only the intercept and the spatially structured random effect. The following lines contain models with the SSRE plus one environmental variable.

d Categorical variable: LS, lower slope, MS, mid slope, PI, plateau, FLL flat low land, AIF, alluvial flooded plot. The corner constraint is used (parameter for LS is set at 0)

Table 2. Results of the beta regression for basal canker severity in 2011.

\begin{tabular}{|c|c|c|c|}
\hline Model & & Parameter $^{\mathrm{a}}$ & $\mathrm{DIC}^{\mathrm{b}}$ \\
\hline $\mathrm{SSRE}^{\mathrm{c}}$ & & & -99.1 \\
\hline+ origin & & $0.142[-0.405,0.716]$ & -96.7 \\
\hline+ land use & & $-0.160[-0.885,0.498]$ & -98.1 \\
\hline$+\log$ (dist. to river) & & $-0.063[-0.333,0.205]$ & -98.2 \\
\hline$+\log ($ tree $d b h)$ & & $-0.339[-1.062,0.417]$ & -96.6 \\
\hline$+\%$ ash in stand & & $0.002[-0.005,0.010]$ & -97.7 \\
\hline+ topography $^{d}$ & LS & $-b$ & -106.1 \\
\hline & MS & $-1.300[-2.213,-0.470]$ & \\
\hline & PI & $-0.690[-1.294,-0.110]$ & \\
\hline & FLL & $-0.866[-1.713,-0.093]$ & \\
\hline & AIF & $-0.499[-1.1$ & \\
\hline + soil pH & & $0.168[-0.642,0$. & -96.7 \\
\hline + waterlogging & & $-0.008[-0$ & -98.7 \\
\hline$+\%$ herbaceous cover & & $0.006[-0.008,0.019]$ & -97.8 \\
\hline + Landolt F & & $1.025[0.004,2.057]$ & -105.1 \\
\hline $\begin{array}{l}\text { + density epiphytic } \\
\text { rhizomorphs }\end{array}$ & & $0.109[-0.300,0.483]$ & -97.3 \\
\hline + Armillaria presence & & $0.832[0.193,1.480]$ & -100.0 \\
\hline
\end{tabular}

\footnotetext{
${ }^{\text {a }}$ Mean $(95 \%$ credibility interval, $\mathrm{Cl})$ Significant results $(\mathrm{Cl}$ does not include 0$)$ are shown in bold font.

${ }^{\mathrm{b}}$ Deviance Information Criteria

c SSRE: model with only the intercept and the spatially structured random effect. The following lines contain models with the SSRE plus one environmental variable.

${ }^{d}$ Categorical variable: LS, lower slope, MS, mid slope, PI, plateau, FLL flat low land, AIF, alluvial flooded plot. The corner constraint is used (parameter for LS is set at 0 ).
}

\section{Relationship to site and stand characteristics}

The crown decline rating could be significantly linked to few stands characteristics. Only the model with the tree size (log of tree $\mathrm{dbh}$ ) had a parameter significantly different from 0 (table 1). The crown decline decreased with tree size.

The \% of collar girdled by the canker showed the same relationship to stand and site characteristics in 2011 and 2012. Only the results for 2011 are shown (Table 2). The stand characteristics, in particular the \% of ash in the stand (Fig. 5b), were not significantly linked to the severity of canker girdling. Only 2 of the measured site characteristics, i.e. the topography and the mean Landolt $F$ value, were significantly linked to the canker 
severity (Table 2). The \% of ash collar girdled by the canker decreased with increasing Landolt $F$ value (Fig. 5a), indicating that humid conditions are favourable to the development of collar cankers. Also, the girdling of ash collar was more pronounced in the lower slope and alluvial flooded plots compared to the mid slope, plateau and flat low lands topographical positions (Fig. 5c).
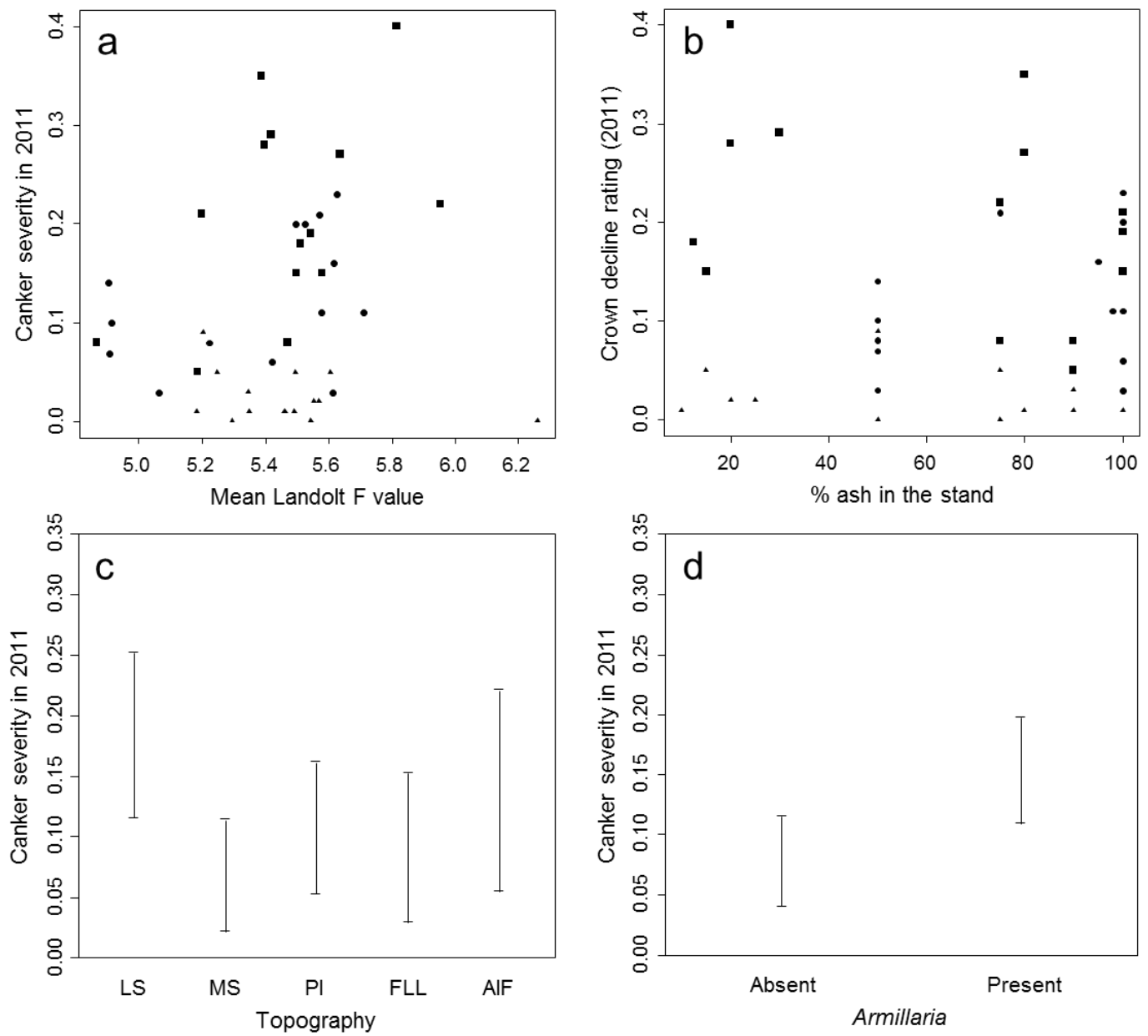

Figure 5. Influence of site and stand factor on the severity of collar lesions. a. Site humidity measured by the mean plot Landolt F value; b. \% of ash in the stand; c. Topography: LS, lower slope, MS mid slope, PI, plateau, FLL, flat low land, AIF, Alluvial flooded site, d. Presence of Armillaria. a, inside the $H$. fraxineus focus, i.e. spatially structured random effect of less than 0.11 , •, intermediate, i.e. spatially structured random effect of 0.11-0.16, closed $\boldsymbol{\Delta}$, outside the $H$. fraxineus focus, i.e. spatially structured random effect of more than 0.16 (see Fig. 1b). 0.11 and 0.16 represent the 0.33 and 0.66 percentile of the spatially structured random effect. Credibility intervals are shown on Fig. 5.c and d.

The amount of Armillaria species epiphytic rhizomorphs present on the collar of the ash trees did not influence the \% of collar girdled by the canker (Table 2). However, collar girdling was more severe in stands where Armillaria species were isolated from the collar (Table 2, Figure 5d). Moreover, it was observed during the survey that cankers invaded by Armillaria species often showed a very developed rot of the lower bole section.

The increase in canker severity in 2012, i.e. canker girdling in 2012 minus canker girdling in 2011 depended strongly on the canker severity in 2011 with no clear spatial effect (DIC of -123.7 for the model including the spatial autocorrelation effect and of -124.5 for the model without). The more severe the girdling was in 2011, the larger the 2011-12 increase was. None of the site and stand parameters measured was significantly related to this evolution (results not shown). In particular, 2 variable did not show any relationship with the 2011-12 canker evolution, the density of apothecia in the litter in 2011 (credibility interval for the associated parameter of $[-0.058,0.042])$ and Armillaria species detection in the plot (credibility interval for the associated parameter of $[-0.556,0.474])$. 


\section{Discussion}

Despite the strong spatial effect that resulted from the invasion history, the analysis approach used enabled to test the hypothesis on environmental effect on the collar canker severity induced by $H$. fraxineus. Armillaria presence did increase the severity of the collar girdling. Among the environmental variable tested, only the site humidity could be linked to the canker severity. At last, we did not observe that the canker evolution was stronger in location with large presence of $H$. fraxineus apothecia in the litter. Also the study showed the strong interest to take the collar canker into account as high tree mortality rate was associated to collar girdling above $75 \%$. Interestingly, the death rate was relatively low (less than $3 \%$ ) in other trees in the studied sites, despite the fact that all sites were located in very infected area and that approximately one-fourth of trees shows severe crown dieback.

As observed in Husson et al. (2012), the large majority of the collar cankers were associated with $H$. fraxineus. While Phytophthora sp. were never detected, Armillaria sp. were commonly isolated. However, Armillaria sp. were seldom observed causing collar lesion alone and were usually found in association with $H$. fraxineus. Moreover, in a third of the plots which were mainly plots with a former agriculture setting, Armillaria sp. was not observed and collar cankers were associated only with $H$. fraxineus. A possibility would be that the molecular detection used for $H$. fraxineus was more efficient than the isolation technique used for Armillaria. However, Chandelier et al (2016) find results similar to our using a molecular detection for both $H$. fraxineus and Armillaria species. When Armillaria species are present on the cankered trees, the girdling of the collar is more pronounced. This does not result in a lower severity of collar canker in former agricultural settings. A possible explanation is that some plots were adjacent to forest and could be readily colonised by Armillaria species. Thus, like that was observed in combined infection by root rot basidiomycetes and Phytophthora sp. on oak seedlings (Marçais et al., 2011). Armillaria sp. and $H$. fraxineus positively interact on the affected ashes to increase the level of collar girdling. Moreover, very severe rot of the collar wood was observed when Armillaria was present. This may have significant consequences for tree stability and causes problems for logging of affected ash stands. Foresters of Northeastern France have started to revise their health and safety rules concerning logging to adapt to this new and more dangerous context. The reduction of stability of ash trees infected by both H. fraxineus and Armillaria could also be very significant for trees in amenity or roadside situations.

In a previous study, Husson et al. (2012) pointed out the possibility of $H$. fraxineus dispersal in ash log as the pathogen is able to produce conidia on fresh infected trunk sections. This is controversial as conidia have been reported to behave only as spermatia and not to be infectious (Kirisits et al., 2009; Gross et al., 2014). However, it remains a risk difficult to evaluate. During this study, most observed collar cankers associated to $H$. fraxineus did not reach high level above the soil (93\% of less than $50 \mathrm{~cm}$ high). Thus, cutting above the infected part of the tree, so that logs do not contain the infected part, provides a safe and easy way to rule out any possible spread by logs and should be recommended to avoid any risk.

Among the site and stands parameters studied few did show a relationship with either the severity of $H$. fraxineus induced cankers or the crown decline. Husson et al. (2012) showed that cankers were more severe in the more humid sites. We attempted to document this more thoroughly in this study; nevertheless, site humidity proved to be difficult to characterize and several tested humidity proxy, i.e. distance to the river, the waterlogging experienced in the plot or the cover of the herbaceous layer that might have influenced the microclimate of the ash rachis in the litter were not linked to the canker severity. However, the study was able to demonstrate that more humid topographical locations such as lower slopes showed a high canker severity. The best site moisture proxy found was derived from the plant community using mean plant Landolt $F$ value for bio-indication (so-called Ellenberg coefficients). More severe girdling by collar canker was observed in site with plants communities associated with a higher moisture status. However, this relationship was not observed for crown decline.

Younger stands, with smaller dbh, were associated with more severe crown decline but not with more severe collar canker as was reported by Husson et al. (2012). This results is however not really robust. The variability in mean stand dbh, i.e. tree trunk diameter, ranged altogether from 5 to $40 \mathrm{~cm}$, but most of stands with large trees were located far from the focus center while stand in the focus center had a maximum of $20 \mathrm{~cm}$ mean $\mathrm{dbh}$. This hypothesis could thus not be well tested. Interestingly, the ash frequency was significantly linked with neither the crown decline nor the collar girdling by the canker, despite a range from 10 to $100 \%$ of ash in the studied stands and the fact that this frequency was well balanced between focus center and focus periphery (Fig. 4b). This would suggest a weak relationship between the disease and the host density at that scale although we did not actually measure ash basal area in the stands. However such a weak relation between ash density and $H$. fraxineus ash dieback has already been reported by Bakys et al. (2013) who studied the disease severity in thinning trials with ash density ranging from 11-150 to 1700-5500 trees.ha-1.

In this work, we studied the relationship between amount of inoculum produced in the litter and site conditions and/or crown status with the underlying hypothesis that as decline increases less litter is produced and thus less $H$. fraxineus inoculum. We also the studied the relationship between evolution of girdling by collar 
lesions and the amount of $H$. fraxineus inoculum produced with the underlying hypothesis that girdling results from the accumulation of new collar infections.

For the first point, we did find some support in our results although limited. The amount of ash rachis in the litter was significantly linked to soil $\mathrm{pH}$, which it is expected as litter decomposition is usually more active in rich soil with eutrophic mull humus. However, this did not result in smaller apothecia density in the litter, whether expressed per amount of ash rachis or in number of apothecia per square meter; these 2 parameters were uncorrelated with the soil $\mathrm{pH}$. Maybe, ash rachis colonized by $\mathrm{H}$. fraxineus do not decompose so well because they are protected by the fungus pseudosclerotia which explain why the pathogen may produce apothecia on a rachis for up to 5 years (Gross and Holdenrieder, 2013; Kirisits, 2015). The amount of rachis / apothecia in the litter also was influenced by the ash decline level. As decline became more severe, less rachis were present in the litter. Nevertheless, as rachis became more infected as evidenced by a higher amount of apothecia per dry weight of rachis, it did not result in a different density of apothecia in the litter per square meter. These results have to be taken with caution as the variable measured may inadequately represent the inoculum production in the stand for several reasons. First we did not separate ash rachis with $H$. fraxineus pseudosclerotia and thus do not have an adequate measure of the amount of infected rachis in the litter. Then, although the determination of apothecia abundance was done in the second half of June, during the main period of $H$. fraxineus fruiting in the area, on single time of measurement might be inadequate to characterize the level of inoculum production. Maybe apothecia abundance should be measured more than once as $H$. fraxineus fruit bodies are produced from June to August. Another way is spore trapping technics as used by Chandelier et al. (2014) which would provide a better estimate of inoculum level as it integrates the influence of a larger area and can be used for more than one day.

The hypothesis that the ash collar girdling occurs because of the accumulation of cankers more than because individual cankers enlarge over years was supported by the data. There was a delay in the development of the canker relative to the crown decline as evidenced by a lower spatial extension. The appearance of collar canker a few years after the first crown symptoms could arise because initiation of collar lesion needs a high level of inoculum production. However, we could not detect any significant relationship between the evolution in collar girdling between 2011 and 2012 and the density of $H$. fraxineus apothecia in the stands. This could be because our measure of the pathogen inoculum level was inadequate as explain before. Also, we determined the apothecia density at the basis of selected ash trees. By doing that, we bias the estimation of apothecia density at the stand level as the \% of ash trees showed a great variability. Alternatively, some ash trees may be very susceptible to collar infection. A recent manuscript (Munoz et al, submitted) shows that variation in resistance to collar canker formation is large in the ash population and that this trait present a high heritability. Maybe, part of the ash population is very susceptible to invasion of the collar by $\mathrm{H}$. fraxineus and cannot restrict individual infection and thus present cankers that enlarge during several years. This might result in cankers that, once initiated, do not really depend on inoculum production by apothecia. Better understanding of conditions linked to collar girdling and whether this depends on continuously high levels of inoculum production might be critical especially because mortality associated with $H$. fraxineus was determined by this collar girdling in this study.

\section{Acknowledgements}

This study was supported by grants from the Département de la Santé des Forêts (French Ministry of agriculture and forestry). The UMR1136 is supported by a grant overseen by the French National Research Agency (ANR) as part of the "Investissements d'Avenir" program (ANR-11-LABX-0002-01, Laboratory of Excellence ARBRE). We wish to thanks the 3 reviewers and Anne Gégout-Petit who help us improving the manuscript by their suggestions.

\section{Reference}

Bakys R, Vasaitis R, Skovsgaard JP, 2013. Patterns and Severity of Crown Dieback in Young Even-Aged Stands of European Ash (Fraxinus Excelsior L.) in Relation to Stand Density, Bud Flushing Phenotype, and Season. Plant Protection Science 49, $120-26$.

Bakys R, Vasiliauskas A, Ihrmark K, Stenlid J, Menkis A, Vasaitis R, 2011. Root Rot, Associated Fungi and Their Impact on Health Condition of Declining Fraxinus Excelsior Stands in Lithuania. Scandinavian Journal of Forest Research 26, $128-35$.

Bakys R, Vasaitis R, Barklund P, Ihrmark K, Stenlid J, 2009. Investigations concerning the role of Chalara fraxinea in declining Fraxinus excelsior. Plant Patholology 58, 284-292.

Blangiardo M, Cameletti M, Baio G, Rue H, 2013. Spatial and spatio-temporal models with R-INLA. Spatial and Spatio-temporal Epidemiology. 4: 33-49.

Chandelier A, Helson M, Dvorak M, Gischer F, 2014. Detection and quantification of airborne inoculum of Hymenoscyphus pseudoalbidus using real-time PCR assays. Plant Pathology 63, 1296-1305.

Chandelier A, Gerarts F, San Martin G, Herman M, Delahaye L, 2016. Temporal evolution of collar lesions associated with ash dieback and the occurrence of Armillaria in Belgian forests. Forest Pathology. DOI 10.1111/efp.12258. 
Enderle R, Peters F, Nakou A, Metzler B, 2013. Temporal development of ash dieback symptoms and spatial distribution of collar rots in a provenance trial of Fraxinus excelsior. European Journal of Forest Reseach 132, 865-876.

Gross A, Holdenrieder O, 2013. On the longevity of Hymenoscyphus pseudoalbidus in petioles of Fraxinus excelsior. Forest Pathology 43, 168-170.

Gross A, Holdenrieder O, 2015. Pathogenicity of Hymenoscyphus fraxineus and Hymenoscyphus albidus towards Fraxinus mandshurica var. japonica. Forest pathology doi: 10.1111/efp.12182

Gross A, Holdenrieder O, Pautasso M, Queloz V, Sieber TN, 2014. Hymenoscyphus pseudoalbidus, the causal agent of European ash dieback. Molecular Plant Pathology 15, 5-21.

Guillaumin JJ, Berthelay S, 1981. Détermination spécifique des Armillaires par la méthode des groups de compatibilité sexuelle. Spécialisation écologique des espèces françaises, Agronomie, 1, 897-908.

Husson C, Caël O, Grandjean JP, Nageleisen L, Marçais B, 2012. Occurrence of Hymenoscyphus pseudoalbidus on infected ash logs. Plant Pathology 61, 889-895.

loos R, Kowalski T, Husson C, Holdenrieder O, 2009. Rapid in planta detection of Chalara fraxinea by a real-time PCR assay using a dual-labelled probe. European Journal of Plant Pathology 125, 329-335.

Kirisits T, Matlakova M, Mottinger-Kroupa S, Cech T, Halmschlager E, 2009. The current situation of ash dieback caused by Chalara fraxinea in Austria. In: Dogmus Lehtijärvi TH, eds, Proceedings of the International Union of Forest Research Organizations, Working Party Foliage, shoot and stem diseases of forest trees, 2009. Egirdir, Tukey: Süleyman Demirel University, Faculty of Forestry, Isparta, p. 21.

Kirisits T, 2015. Ascocarp formation of Hymenoscyphus fraxineus on several-year-old pseudosclerotial leaf rachises of Fraxinus excelsior (S Woodward, Ed,). Forest Pathology, 45, 254-257

Kowalski T, 2006. Chalara fraxinea sp. nov. associated with dieback of ash (Fraxinus excelsior) in Poland. Forest Pathology 36, 264270.

Landolt E, 1977. Ökologische Zeigerwerte zur Schweizer Flora. Zürich, CH: Stiftung Rübel.

Lindgren F, Rue H, Lindstrom J, 2011. An explicit link between Gaussian fields and Gaussian Markov random fields: The SPDE approach (with discussion). Journal of the Royal Statistical Society, Series B, 73, 423-498.

Marçais B, Caël O, 2006. Spatial pattern of the density of Armillaria epiphytic rhizomorphs on tree collar in an oak stand. Forest Pathology 36, 32-40.

Marçais B, Caël O, Delatour C, 2011. Interaction between root rot basidiomycetes and Phytophthora species on pedunculate oak. Plant Pathology 60, 296-303.

McKinney LV, Nielsen LR, Colling DB, Thomsen IM, Hansen JK, Kjær ED, 2014. The ash dieback crisis: genetic variation in resistance can prove a long-term solution. Plant Pathology 63, 485-499.

Muñoz F, Marçais B, Dufour J, Dowkiw A, 2016. Rising out of the ashes: additive genetic variation for susceptibility to Hymenoscyphus fraxineus in Fraxinus excelsior (submitted).

Orlikowski LB, Ptaszek M, Rodziewicz A, Nechwatal J, Thinggaard K, Jung T, 2011. Phytophthora root and collar rot of mature Fraxinus excelsior in forest stands in Poland and Denmark. Forest Pathology 41, 510-519.

Rue H, Martino S, Chopin N, 2009. Approximate Bayesian inference for latent Gaussian models using integrated nested Laplace approximations (with discussion). Journal of the Royal Statistical Society, Series B, 71, 319-392.

Schumacher J, 2011. The general situation regarding ash dieback in Germany and investigations concerning the invasion and distribution strategies of Chalara fraxinea in woody tissue. EPPO Bulletin 41, 7-10.

Skovsgaard JP, Thomsen IM, Skovgaard IM, Martinussen T, 2010. Associations between symptoms of dieback in even-aged stands of ash (Fraxinus excelsior L.). Forest Pathology 40, 7-18. 